\title{
SOMATOTROPHIC AND CORTICOTROPHIC FUNCTION OUTCOME AFTER TRANSESPHENOIDAL SURGERY IN PATIENTS WITH SELLAR TUMORS AND PRE-OPERATIVE ENDOCRINE DEFICITS
}

\author{
FERNANDO R. PIMENTEL-FILHO*, LUIS ROBERTO SALGADO*, \\ ARTHUR CUKIERT ** BERNARDO LIBERMAN*
}

\begin{abstract}
Sixteen patients with sellar tumors that were treated surgically and who had pre-operative somatotrophic and corticotrophic function deficits were submitted to pre- and early post-operative insulin tolerance tests (ITTs). Seven patients had non-functioning adenomas, 5 had prolactinomas, 3 had craniopharyngioma and 1 had cordoma of the clivus. All patients had macro-tumors and none received radiotherapy within the studied period. Seven patients had GH, 4 had cortisol and 5 had both $\mathrm{GH} /$ cortisol function pre-operative deficit. Five patients with isolated $\mathrm{GH}, 4$ with isolated cortisol and 3 with both $\mathrm{GH} /$ cortisol deficiencies showed a postoperative functional recovery. New cortisol secretion deficits were observed in 2 patients postoperatively and both required long-term steroid replacement. These data suggest that preoperative endocrine deficits may be reversible after surgical decompression of the sellar region and that new endocrine deficits are rarely seen after surgery. All such patients should be tested postopcratively from an endocrinological point of view to reevaluate the need for replacement therapies
\end{abstract}

KEY WORDS: pituitary tumors, transesphenoidal surgery, endocrine deficits.

Evoluçāo das funções somatotrófica e corticotrófica após cirurgia transesfenoidal em pacientes com tumores selares e déficits endócrinos pré-operatórios

RESUMO - Dezesseis pacientes com tumores da região selar que foram tratados cirurgicamente e que possuiam déficits funcionais dos eixos somatotrófico ou corticotrófico foram submetidos a teste de tolerância ḋ insulina pré- c pós-operatoriamente. Sete pacientes possuíam adenomas não-funcionantes, 5 possuíam prolactinomas, 3 craniofaringiomas e 1 possuía cordoma de clivus. Todos os pacientes possuíam macrotumores e nenhum deles foi submetido a radioterapia durante o período do estudo. Sete pacientes possuíam deficiência isolada do setor somatotrófico, 4 isolada do setor corticotrófico e 5 possuíam deficiência de ambos os setores. Cinco pacientes com deficiência isolada do setor somatotrófico, 4 com deficit isolado do setor corticotrófico e 3 com deficiência nos dois setores obtiveram melhora funcional pós-operatoriamente. Novos déficits do setor corticotrófico ocorreram em 2 pacientes, que necessitaram reposição de esteróides por longo prazo. Estes dados sugerem que déficits endócrinos pré-operatórios podem ser revertidos pela descompressão cirúrgica da região selar e que novos deficits causados pela cirurgia são raros. Estes pacientes devem ser retestados pós-operatoriamente do ponto de vista endócrino para se determinar a necessidade de terapia de reposição hormonal.

PALAVRAS-CHAVE: tumores pituitários, cirurgia transesfenoidal, déficits endócrinos.

Hypogonadotrophic hypogonadism and growth hormone deficiency (GHd) are the most common hormonal abnormalities in patients with tumors in the sellar region ${ }^{1.18}$. The pituitary-adrenal axis is less affected than the others by such tumors ${ }^{1.18 .19}$. Both improvement or worsening in one or more endocrine axis have already been documented after surgery for pituitary tumors with or without

*Serviços de Endocrinologia e de **Neurocirurgia do Hospital Brigadeiro, Sāo Paulo Aceite: 9-abril-1997. 


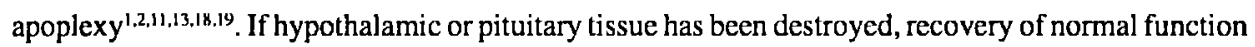
is unlikely, and lifelong hormone-replacement therapy is required. However, partial or complete recovery of pituitary function occurred in the majority of the patients (65\%) with non-functioning pituitary adenomas submitted to transesphenoidal surgery studied by Arafah'; thyroidal function improved in $57 \%$, gonadal function in $32 \%$ and pituitary-adrenal function in $38 \%$ of the patients ${ }^{1}$. Somatotrophic function had fully recovered in only a small number of patients postoperatively (0$27 \%)^{1,18,11}$. However, in most of these studies the adult GH deficiency has been defined based on studies in children and the wide variation in the "cut-off" of peak GH response to a standard provocative test could have contributed to this small rate of somatotrophic recovery.

The mechanisms by which pituitary tumors cause hypopituitarism include mechanical compression of normal pituitary tissue by the tumor, impaired blood flow to the normal tissue, and interference with the delivery of hypothalamic regulating hormones through the hypothalamichypophysial portal system.

In this paper we analised the effects of transesphenoidal surgery on somatotrophic and corticotrophic deficiencies seen in patients with sellar tumors and elaborated on the usefulness of re-evaluating these patients from an endocrinological point of view after surgery.

\section{METHODS}

Sixteen patients ( 11 women and 5 men) who have undergone transesphenoidal surgery for the treatment of sellar tumors were retrospectively evaluated. Age ranged from 19 to 45 years (mean $=31 \pm 2$ years) and BMI was $24.4 \pm 0.5 \mathrm{Kg} / \mathrm{m}^{2}$. Only patients who had $\mathrm{GH}$ or cortisol deficiencies as shown by an insulin tolerance test (ITT) preoperatively were included in this study. No patient underwent radiotherapy. Seven patients had clinically nonfunctioning adenomas, 5 had prolactinomas, 3 had craniopharyngioma and 1 had a cordoma of the clivus. All patients had large tumors (with sellar and supra-sellar extention) demonstrated by computerized tomographic scanning. In one of the patients with craniopharyngioma the tumor presented solid and cystic components. Clinical symptoms suggestive of hypogonadism associated with reduced basal levels of gonadotrophins and estradiol (in women) or testosterone (in men) were observed in 12 of 16 patients preoperatively. No patient had clinical or biochemical signs suggesting hypothyroidism or other systemic disorder.

All patients have undergone an ITT $(0.1 \mathrm{U} / \mathrm{Kg}$ of regular insulin) to evaluate GH and cortisol secretion before and after surgery. After an overnight fast, an antecubital vein was punctioned early in the moming and kept patent by slow saline infusion. Basal blood sampling was performed 30 minutes afterwards and insulin was then administered in bolus. Subsequent samples were collected at 15,30, 45, 60 and 90 minutes after insulin injection for glucose and hormonal levels determination. The postoperative evaluation was performed until 3 months after surgery. Patients were kept out of any medication for at least 2 weeks before the test. Those who showed basal levels of cortisol below $5 \mathrm{ug} / \mathrm{dl}$ or a low response of cortisol to ITT preoperatively received cortisone acetate during surgery and in the immediate postoperative period, which was progressively tappered down within the first postoperative week whenever possible.

Serum GH concentrations were measured by immunoradiometric methods, using a commercially available kit from Pharmacia (Uppsala, Sweden). The limit of detection of GH was $0.5 \mathrm{ng} / \mathrm{ml}$, and the intra- and interassay coefficients of variation were $7.3 \%$ and less than $10 \%$, respectively. The samples from the two tests (pre - and postoperative) from each patient were measured in the same assay. GHd was diagnosed if peak GH level did not reach a value of $5.0 \mathrm{ng} / \mathrm{ml}$ after insulin-induced hypoglycaemia $(<45 \mathrm{mg} / \mathrm{dL})^{12}$. Plasma concentrations of cortisol were measured by radioimmunoassay, using kits from Baxter-Clinical (Stillwater, MA, USA), and the intra- and interassay coefficients of variation were $7.0 \%$ and $9.0 \%$, respectively. The diagnosis of cortisol deficiency was established if the peak cortisol level was lower than $18 \mu \mathrm{g} / \mathrm{dL}$ following hypoglycemia ${ }^{3}$. The other hormonal measurements (T3, T4, TSH, LH, FSH and PRL) were performed by radioimmunoassay, using commercially available kits, which have interassay coefficients of variation below $12 \%$ (data not presented).

The Wilcoxon test was used to compare the peak GH and cortisol levels in the pre- and postoperative evaluations. The results were expressed in mean \pm SEM values. A " $p$ " value lower than 0.05 was considered statistically significant. 


\section{RESULTS}

All patients got effective ITTs (glicemia below $45 \mathrm{mg} / \mathrm{dl}$ ). Twelve patients had GHd (7 with isolated GHd and 5 with GHd plus cortisol deficiency) and 4 had isolated cortisol deficiency. The preoperative mean GH peak for the 12 patients with GHd was $1.5 \pm 0.2 \mathrm{ng} / \mathrm{ml}$ (range: $0.5-3.1$ ). Postoperatively, 7 (58.3\%) of these patients showed GH peaks higher than those observed preoperatively $(11.6 \pm 2.8 \mathrm{ng} / \mathrm{ml})(\mathrm{p}=0.02)$, being between 5 to $7 \mathrm{ng} / \mathrm{ml}$ in 3 patients and above $7 \mathrm{ng} /$ $\mathrm{ml}$ in the others (Fig 1). Five out of the 7 patients with isolated GHd in the preoperative evaluation recovered GH secretion after surgery. The patients with cortisol deficiency had a mean cortisol peak of $9.5 \pm 1.5 \mathrm{ug} / \mathrm{dl}$ preoperatively. Six of these paticnts $(67 \%)$ disclosed a normal cortisol response during the ITT after surgery (peak cortisol $=23.4 \pm 2.1 \mu \mathrm{g} / \mathrm{dI})(\mathrm{p}=0.03$ ) (Fig 2). Three of the 5 patients with $\mathrm{GH}$ plus cortisol deficiencies preoperatively recovered some endocrine function after surgical treatment: 1 patient with prolactinoma recovered $\mathrm{GH}$ and cortisol secretion and the other 2 recovered only one endocrine function ( $\mathrm{GH}$ or cortisol secretion).

Patients with isolated $\mathrm{GH}$ or cortisol deficiencies preoperatively had an $82 \%$ recovery rate after surgical treatment (9/1.1). In those with both $\mathrm{GH}$ and cortisol deficiencies before surgery, the rate of recovery of at least one of the pituitary axis was $60 \%(3 / 5)$.

Postoperative impaired cortisol secretion was observed in 2 patients with isolated GHd preoperatively and both required chronic steroid replacement therapy. Surgery did not induce GHd in those patients with isolated cortisol deficiency preoperatively. Table 1 shows the distribution of the preoperative hormonal deficiencies and the endocrine outcome after surgery. Five of the 7 patients with nonfunctioning macroadenomas recovered $\mathrm{GH}$ or cortisol secretion postoperatively. Only 1 of the 5 patients with prolactinoma remained with partial cortisol deficiency postoperatively and did not require chronic replacement therapy. Prolactin levels were reduced in all patients with prolactinoma after surgery and were normal in 3. The other 2 had prolactin levels of 1030 and 550 postoperatively. It was not possible to establish any statistical difference on the endocrine recovery rate between

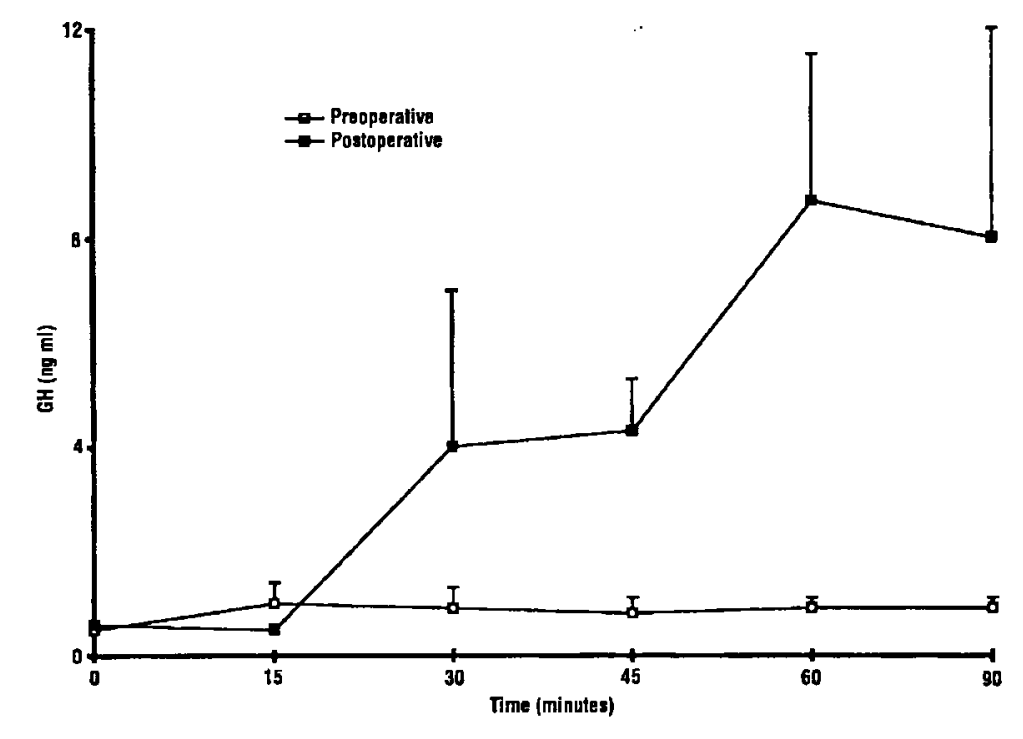

Fig 1. Preoperative $G H$ deficiency and its postoperative recovery in patients surgically treated for sellar tumors $(n=7 ;$ Mean $+S E M)$. 


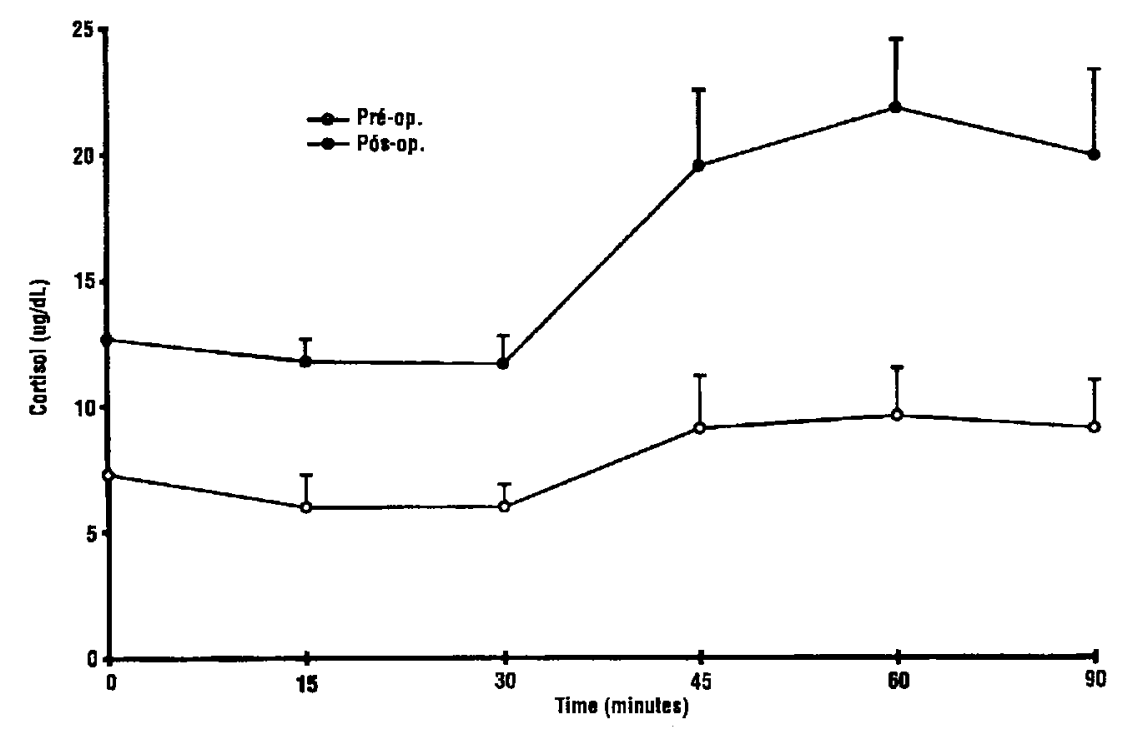

Fig 2. Preoperative cortisol deficiency and its postoperative recovery in patients surgically treated for sellar tumors $(n=6 ;$ Mean $+S E M)$.

patients with prolactinoma with normal or abnormal postoperative prolactin levels (small " $n$ "). All patients with craniopharyngioma disclosed GHd before surgery and none had cortisol deficiency. One of them obtained a GH secretion recovery (with peak GH of 19.0 and $14.0 \mathrm{ng} / \mathrm{ml}$ in two postoperative ITT) but in 2 there was a worsening of the cortisol response to the ITT'. The patient with cordoma recovery its GHd after surgical treatment.

Table 1. Somatotrophic and corticotrophic functions in adult patients with sellar tumors before and after surgery: preoperative/postoperative individual hormonal peak, during ITT.

\begin{tabular}{|c|c|c|c|c|c|}
\hline \multirow[b]{3}{*}{$\begin{array}{l}\text { Preoperative } \\
\text { hormonal } \\
\text { deficiency }\end{array}$} & \multicolumn{4}{|c|}{ Type of Tumor } & \multirow[b]{3}{*}{$\begin{array}{l}\text { Total of patients } \\
\text { with postoperative } \\
\text { recovery }\end{array}$} \\
\hline & \multicolumn{4}{|c|}{ Individual peak of GH (ng/ml) and/or cortisol (ug/dL) } & \\
\hline & $\begin{array}{l}\text { Nonfunctioning } \\
\text { macroadenoma } \\
(n=7)\end{array}$ & $\begin{array}{l}\text { Prolactinoma } \\
\qquad(\mathrm{n}=5)\end{array}$ & $\begin{array}{l}\text { Craniopharyngioma } \\
\qquad(n=3)\end{array}$ & $\begin{array}{c}\text { Cordoma } \\
(n=1)\end{array}$ & \\
\hline GH & $3.1 / 6.2$ & $\begin{array}{l}1.1 / 7.1 \\
0.9 / 5.0\end{array}$ & $\begin{array}{l}2.1 / 19.0 \\
2.4 / 0.3 \\
1.9 / 0.3\end{array}$ & $0.5 / 6.8$ & 5 \\
\hline Cortisol & $\begin{array}{l}6.2 / 24.9 \\
11.0 / 19.0 \\
16.0 / 19.0\end{array}$ & $16.1 / 25.4$ & - & - & 4 \\
\hline GH+cortisol & $\begin{array}{c}\text { (GH)-(Cortisol) } \\
(1.6 / 3.6)-(9.3 / 18.0) \\
(1.2 / 3.9)-(5.8 / 16.5) \\
(1.5 / 1.2)-(7.8 / 9.6)\end{array}$ & $\begin{array}{c}\text { (GH)-(Cortisol) } \\
(1.3 / 12.8)-(4.4 / 34.0) \\
(1.4 / 24.2)-(12.0 / 10.0)\end{array}$ & ) & - & 3 \\
\hline
\end{tabular}




\section{DISCUSSION}

GH release after an insulin-induced hypoglycaemia may be impaired in adult patients with sellar tumors. This can also occur after irradiation or surgery of this region ${ }^{6,10,12,17,21-23}$. Although there is no consensus of which would be the best method to detect GHd in adults ${ }^{6,7,12,21}$, Hoffman et al. ${ }^{12}$ have demonstrated that the ITT is extremely accurate in differentiating subjects with organic GHd from normal matched subjects. In Hoffman's series, GHd adults had a GH peak lower than 3.1 $\mathrm{ng} / \mathrm{ml}$ during the ITT, which is significantly lower than the control subjects that had GH peaks higher than $5.0 \mathrm{ng} / \mathrm{ml}$. Furthermore, GH release after the ITT is not reduced in idiopatic hyperprolactinemia". Although some authors would consider the diagnosis of adult onset GHd in all patients with a GH peak lower than $7-10 \mathrm{ng} / \mathrm{ml}$, the mean GH peak seen in most of their patients were lower than $3.5 \mathrm{ng} / \mathrm{ml}$, suggesting that in this disorder the GH peak after ITT is very low ${ }^{17,22,25}$. We have accepted Hoffman's criteria for the diagnosis of adult-onset GHd in this paper. Surprisingly, our data showed that $58.3 \%$ of the patients with GHd preoperatively had an improvement in $\mathrm{GH}$ secretion (GH pcak higher than $5.0 \mathrm{ng} / \mathrm{ml}$ ) postoperatively. This rate of recovery after surgery is higher than previously reported ${ }^{1,18,19}$. Arafah' reported a high incidence of GHd (near 100\%) preoperatively in patients with nonfunctioning pituitary adenoma and that GH secretion's recovery was not frequent postoperatively (15\%). The cutoff value for the diagnosis of GHd in our study $(5.0$ $\mathrm{ng} / \mathrm{ml}$ ) was lower than that used in their study $(8.0 \mathrm{ng} / \mathrm{ml})$ and this could have influenced our postoperative results. The same author ${ }^{1}$ had observed that the mean tumor size in patients recovering pituitary function was significantly smaller than that in patients with persistent hypopituitarism. Unfortunately, it is often difficult to compare different series in terms of tumor volume and size.

Many authors ${ }^{5,8,16,18,24}$ have demonstrated that preoperative adenohypophyseal dysfunction was not reversed by surgery in most of patients with craniopharyngioma and that most of them experienced new endocrinological deficits after surgery. However, Barreca et al. ${ }^{4}$ reported $\mathrm{GH}$ secretion recovery postoperatively in patients with craniopharyngioma. One of our patients with craniopharyngioma also recovered the somatotrophic function postoperatively.

Pituitary-adrenal function improved in $67 \%$ of our patients with preoperative ACTH deficiency. Immediate recovery of pituitary-adrcnal function has been described previously in approximately $65 \%$ of the patients with macroadenomas ${ }^{3}$. Pituitary ACTH secretion deficits or impaired ACTH reserve is not as frequent as $\mathrm{GH}$ deficiency preoperatively in patients with sellar tumors. ACTH secretion deficiency has been described in $5-62 \%$ of the patients with macroadenomas or craniopharyngioma $^{1,18,19}$. Moreover, postoperative pituitary-adrenal deficiency is not so frequent $t^{3,13}$. Two of our patients with craniopharyngioma developed permanent ACTH deficiency postoperatively and one patient with prolactinoma remained with partial deficiency that did not require steroid replacement for a long time.

The pathophysiological mechanisms causing partial or total hypopituitarism in patients with sellar tumors are not yet completely understood. The recovery of pituitary function in most patients after transesphenoidal surgery suggest that there is viable pituitary tissue preoperatively, which is transiently unable to secrete, possibly as a result of altered hypothalamic regulation ${ }^{13}$. It is possible to demonstrate some preserved pituitary function with the use of synthetic hypothalamic peptides like GHRH, TRH and GnRH in patients with hypothalamic-pituitary disconnection due to pituitary stalk transection or tumors of this area ${ }^{14,20}$. It has been showed that the preoperative serum prolactin level is higher in patients who recovered pituitary function after adenomectomy than in those who did not ${ }^{1,3}$. High intrasellar pituitary tissue pressure and pituitary stalk compression were previously demonstrated ${ }^{15}$ and could be the most important factor to induce pituitary deficiencies by comprimising blood flow through the portal vessels. Surgery with removal of the tumor could induce decompression of the pituitary stalk and reduce intrasellar pituitary pressure, allowing for the recovery of some or all hypothalamic-pituitary axis. 
In summary, this study demonstrated that in patients with sellar tumors preoperative cortisol and $\mathrm{GH}$ deficiencies may be reversible after surgical decompression and that hormonal deficiency is not frequently induced by surgery. All such patients should be tested postoperatively from an endocrinological point of view to reevaluate the need for replacement therapies.

\section{REFERENCES}

1. Arafah BM. Reversible hypopituitarism in patients with large nonfunctioning pituitary adenomas. J Clin Endocrinol Metab 1986:62:1173-1179.

2. Arafah BM, Harrington FJ, Mudhoun ZT, Selman WR. Improvement of pituitary function after surgical decompression for pituitary tumor apoplexy. J Clin Endocrinol Metab 1990;71:323-328.

3. Arafah BM, Kailani SH, Nekl KE, Gold RS, Selman WR. Immediate recovery of pituitary function after transesphenoidal resection of pituitary macroadenomas. J Clin Endocrinol Metab 1994:79:348-354.

4. Barreca T, Perria C, Francaviglia N, Rolandi E. Evaluation of anterior pituitary function in adult patients with craniopharyngiomas. Acta Neurochirurgica 1984;71:263-272.

5. Baskin DS, Wilson CB. Surgical management of craniopharyngiomas. J Neursurg 1986;65:22-27.

6. Baum HBA, Biller BMK, Katznelson L. Assessment of growth hormone (GH) secretion in men with adult-onset GH deficiency compared with that in normal men: a clinical research center study. J Clin Endocrinol Metab 1996;81:84-92.

7. Boer H, Blok G-J, Veen EAVD. Clinical aspects of growth hormone deficiency in adults. Endocrine Rev 1995;16:63-85.

8. Brauner R, Malandry F, Rappaport R, Pierre-Kahn A, Hirsch JF. Craniopharyngiomas de l'enfant. Arch Franç Ped 1987;44:765-769.

9. Chang RJ, KeyeWR Jr, Monroe SE, Jaffe RB. Prolactin-secreting pituitary adenomas in women. Pituitary function in amenorrhea associated with normal or abnormal serum prolactin and sellar polytomography. J Clin Endocrinol Metab 1980;51:830-835.

10. Degerblad M, Elgindy N, Hall K, Sjoberg HE, Thoren M. Potent effect of recombinant growth hormone on bone mineral density and body composition in adults with panhypopituitarism. Acta Endocrinol (Copenh) 1992;126:387-393.

11. Harris PE, Afshar F, Coates P, Doniach I, Wass JAH, Besser G.M, Grossman A. The effects of transesphenoidal surgery on endocrine function and visual fields in patients with functionless pituitary tumours. Quart J Med 1989;71:417-427.

12. Hoffman DM, O'Sullivan AJ, Baxter RC, Ho KKY. Diagnosis of growth-hormone deficiency in adults. Lancet 1994;343:1064-1068.

13. Hout WB, Arafah BM, Salazar R, Selman WR. Evaluation of the hypothalamic-pituitary-adrenal axis immediately after pituitary adenomectomy: is perioperative steroid therapy necessary? J Clin Endocrinol Metab 1988;66:1208-1212.

14. Kikuchi K, Fujisawa I, Momoi T. Hypothalamic-pituitary function in growth hormone-deficient patients with pituitary stalk transection. J Clin Endocrinol Metab 1988;67:817-823.

15. Lees PD, Pickard JD. Hyperprolactinemia, intrasellar pituitary tissue pressure, and the pituitary stalk compression syndrome. J Neurosurg 1987;67:192-196.

16. Newman CB, Levine LS, New MI. Endocrine function in children with intrasellar and suprasellar neoplasms. Am J Dis Child 1981;135:259-262.

17. Orme SM, Sebastian JP, Oldroyd B, Stewart SP, Grant PJ, Stickland MH, Smith MA, Belchetz PE. Comparison of measures of body composition in a trial of low dose growth hormone replacement therapy. Clin Endocrinol 1992;37:453-459.

18. Paja M, Lucas $T$, Garcia-Uria J, Salamé F, Barceló B, Estrada J. Hypothalamic-pituitary dysfunction in patients with craniopharyngioma. Clin Endocrinol 1995;42:467-473.

19. Pelkonen R, Grahne B, Hirvonen E, Karonen S-L, Salmi J, Tikkanen M, Valtonen S. Pituitary function in prolactinoma: effect of surgery and postoperative bromocriptine therapy. Clin Endocrinol 1981;42:467-473.

20. Poppovic V, Damhanovic S, Micic D, Djurovic M, Dieguez C, Casanueva FF. Blocked growth hormone-releasing peptide (GHRP-6)-induced GH secretion and absence of the synergic action of GHRP-6 plus GH-releasing hormone in patients with hypothalamopituitary disconnection: evidence that GHRP-6 main action is exerted at the hypothalamic level. J Clin Endocrinol Metab 1995;80:942-947.

21. Reutens AT, Hoffman DM, Leung K-C, Ho KKY. Evaluation and application of a highly sensitive assay for serum growth hormone (GH) in the study of adult GH deficiency. J Clin Endocrinol Metab 1995;80:480-485.

22. Rosen T, Bosaeus I, Tolli J, Lindstedt G, Bengtsson BA. Increased body fat mass and decreased extracellular fluid volume in adults with growth hormone deficiency. Clin Endocrinol 1993;38:63-71.

23. Salomon F, Cuneo RC, Hesp R, Sonksen PH. The effects of treatment with recombinant human growth hormone on body composition and metabolism in adults with growth hormone deficiency. N Engl J Med 1989;321:1797-1803.

24. Thomsett MJ, Conte FA, Kaplan SL, Grumbach MM. Endocrine and neurologic outcome in childhood craniopharyngioma: review of effect of treatment in 42 patients. J Pediatr 1980;97:728-735.

25. Whitehead HM, Boreham C, Mcllrath EM, Sheridan B, Kennedy L, Atkinson AB, Hadden DR. Growth hormone treatment of adults with growth hormone deficiency: results of a 13 month placebo controlled cross-over study. Clin Endocrinol 1992;36:45-52. 